\title{
Introduction: the financial crisis and the politics of international tax cooperation
}

The ongoing financial crisis, which first disrupted world markets in early 2008 , is now entering its fifth year, and the outlook for the global economy remains as fragile as ever. Despite the initial success of the policy responses to the crisis devised by G20 leaders, the tepid recovery of 2009 and 2010 has waned as unprecedented levels of sovereign debt have triggered renewed financial instability in the eurozone and beyond. The political and economic malaise which continues to threaten the global economy has many dimensions. Through a detailed analysis of one aspect of the regulatory response to the financial crisis - international tax cooperation - this book examines the ways in which the ongoing crisis has influenced patterns of international economic cooperation and assesses the prospects of providing effective global governance. In addressing these issues this book aims to shed light on what is emerging as one of the critical questions of our age: Does the international system have the political capacity to devise and implement an effective governance response to the grave challenges currently facing the global economy?

The analysis that follows focuses on one dimension of the international policy response to the financial crisis - albeit a critically important one. The detailed analysis of the politics of international tax cooperation presented in this book is motivated by three sets of considerations. First, improved international tax cooperation in general and increased tax transparency and information exchange in particular promise to enhance the capacity of national governments to tax the offshore assets of resident individuals and companies. Even before the onset of the financial crisis international tax evasion was regarded as a significant and growing problem. Estimates vary, but there is a rough consensus that governments may lose as much as \$US300 billion per annum through international tax evasion (Palan et al. 2010, 63; Hollingshead 2010). The threat of international tax evasion has long been a concern to relatively high-tax European welfare states, but as the financial crisis has evolved into a severe sovereign debt crisis the goal of improving international tax enforcement and compliance now enjoys broad-based support.

International taxation is also an important case study because of the 
nature of the governance problem at the heart of tax cooperation and the institutional structure of the international tax regime. International tax cooperation represents a critical test of governance capacity in the aftermath of the financial crisis because despite the growing resolve among world leaders to address the problem, the reality is that reaching and enforcing international tax agreements is notoriously difficult. This is because national governments (even within the European Union) fiercely defend their sovereign right to tax and spend in accordance with domestic political imperatives. Moreover, while there is a consensus that enhanced international tax cooperation would yield global welfare benefits, there are also powerful economic incentives for individual countries to defect from any agreement. As will be explained in greater detail in Chapter 2, international tax cooperation represents a collaboration problem; a problem that is traditionally difficult to resolve without robust enforcement procedures that can be imposed on potential defectors. Despite the governance challenges involved, the importance of an effective international tax regime for global commerce has led to the formation of a complex legal, diplomatic and organisational apparatus which aims to promote international tax cooperation. Given this level of institutionalisation this study presents an opportunity to assess the ability of international regimes to promote cooperation in relation to contested collaboration problems. In short, the international tax arena can yield important lessons concerning global economic governance in the twenty-first century.

Finally, the case of international tax cooperation has been widely lauded as one of the more successful examples of international cooperation and regulatory reform arising from the financial crisis. Keen to highlight their diplomatic achievements, world leaders and senior tax officials argue that more international tax agreements were delivered in the 10 months following the G20's endorsement of the OECD's standard for tax information exchange in early 2009 than was achieved in the preceding 10 years (Gurria 2009). The contrast between this apparent success in relation to international taxation cooperation compared to other regulatory arenas, where progress has been more problematic, raises a number of questions. Was cooperation enhanced by an existing policy consensus, or can the process be explained in terms of strategies and diplomatic efforts employed by the organisations and actors at the heart of the regime? Or were the changing economic incentives and new ideas emerging from the crisis important drivers of regime change and cooperation? Finally, how did changing domestic political factors influence the policy preferences of key states in the international tax regime? By systematically exploring these questions this book will evaluate the complex ways in which the financial crisis shaped the international reform agenda and the political 
and economic context in which international tax cooperation occurs. On a less sanguine note, the book concludes by arguing that despite the progress that has been made in terms of brokering international tax agreements, very significant barriers to effective implementation and ongoing compliance remain, threatening the sustainability of the regime. This more pessimistic assessment concerning the effectiveness of the regime poses fundamental questions about the prospects of achieving effective global economic governance in the aftermath of the financial crisis.

In order to explore these themes the book presents a historical account of the evolution of the international tax regime, or 'the sets of rules and decision-making procedures that give rise to social practices and assign roles to participants and govern their interactions' in the international tax arena (Young 1999, 5). Within this broad field of enquiry there is a particular emphasis on attempts to broker international agreements to restrict international tax evasion or the unlawful concealment of income and assets in order to avoid tax obligations, although it must also be noted that in practice this distinction between legal tax avoidance and illegal tax evasion is subject to the vagaries of legal interpretation (Picciotto 2011, 226). This historical approach is necessary because established practices, ideas and institutions provide both the context in which contemporary governance problems are defined and the strategies and resources that can be drawn upon in order to solve them. This longitudinal research strategy is also necessary in order to assess regime dynamics, or the ways in which patterns of international cooperation vary over time and the political and economic causes of such changes.

In addition to providing a historical account of the evolution of international tax cooperation in general and of tax information exchange in particular, the analysis that follows is designed to enhance our theoretical understanding of the dynamics of international regime change and the role of the financial crisis in shaping patterns of international tax cooperation. As will be outlined in greater detail in Chapter 2, there is an extensive and diverse literature encompassing both rationalist and sociological traditions on the politics of international cooperation. A common theme in the most recent contributions to this scholarship is the need for empirically grounded 'synthetic interpretations of change' which analyse the diverse factors influencing the nature and effectiveness of international agreements (Keohane 2009, 40). Reflecting this theoretical ambition, Chapters 3 to 6 are designed to assess the relative importance of material, institutional, ideational and domestic political variables in shaping patterns of cooperation in the international tax arena. 


\section{THE REFORM AGENDA}

International taxation is mind bogglingly complex. Basic principles concerning which jurisdiction has the right to tax an international transaction may be relatively straightforward, but the complexity of global commerce combined with years of entrepreneurial (and increasingly aggressive) tax planning have spawned complex provisions concerning all manner of specialist topics from 'thin capitalisation' to 'transfer pricing', and from 'permanent establishment' to 'controlled foreign corporations'. While technical debates concerning each of these regulatory issues are important, in public debate at least they have been eclipsed by the growing political controversy concerning tax transparency and information exchange. As is explained in greater detail in the next chapter, the most egregious and common cases of international tax evasion involve the deliberate nondisclosure of assets and investments concealed in what are commonly described as 'tax havens' or 'secrecy jurisdictions'. The reform agenda that has dominated the international tax policy debate since the mid-1990s concerns creating a regime to promote tax transparency by establishing procedures for tax and financial information exchange between tax authorities with a view to creating an environment in which governments can accurately determine their residents' worldwide income, including funds held offshore. Few would argue that reaching agreement on and implementing an effective regime for tax information exchange would resolve all of the challenges and controversies associated with international tax avoidance and competition, but most concur that such an agreement would represent unprecedented progress towards the broader goal of creating an efficient, equitable and sustainable framework for taxing capital income. Given the prominence of the political debate associated with tax information exchange and the potential impact it could have on international tax evasion, this book focuses on the politics of the international tax transparency regime.

\section{THE POLITICS OF INTERNATIONAL TAX COOPERATION}

Taxation is best regarded as a necessary evil. Tax revenue may be the financial lifeblood of the modern state yet even in the face of spiralling budget deficits, governments the world over find it increasingly difficult to make a political or economic case to increase taxation (Sachs 2011; Martin 2009). The increasingly problematic nature of the fiscal contract may be most apparent in the domestic context but it applies equally to 
international taxation. At this level governments want to maximise their tax take without compromising their ability to attract mobile international investment (Webb 2004). This basic rationale has informed many strategies, from the creation of preferential tax regimes, such as that introduced in Ireland in the late 1990s to attract investment into strategic industries, to the more general trend towards taxing mobile capital more generously than labour income or consumption (Blue 2000). The same logic explains the growth of tax havens, which in a general sense can be defined as jurisdictions whose 'laws and other measures can be used to evade or avoid the tax laws or regulations of other jurisdictions' (TJN 2007). This general definition provides a useful foundation for the analysis that follows, but given our interest in tax transparency, this book focuses on the closely related concept of a 'secrecy jurisdiction', or 'a state, dependency or other form of government which is either unable to obtain, unwilling to hold, or reluctant to share tax and financial information in accordance with accepted international practices and agreements' (OECD 2000). Whereas some jurisdictions may have historically been defined as tax havens because they impose low or non-existent taxation, or perhaps because they offered preferential tax rates to foreign investors, our concern is with the financial secrecy that is the root cause of international tax evasion.

This subtle distinction between a secrecy jurisdiction and a tax haven is also important because, as the analysis presented in this book will highlight, some wealthy high-tax states that would not traditionally be categorised as tax havens may conceal the identities of offshore investors in order to attract foreign capital. In short, both traditional tax havens and wealthy industrialised states have used tax and financial secrecy to promote foreign investment. Finally, while the definition of secrecy jurisdictions provided above is central to the analysis below, it is important to note there is an ongoing debate concerning what constitutes accepted 'international practice' given that no jurisdiction wants to be accused of being in breach of accepted international standards. This debate over establishing an appropriate standard for tax information exchange and the process for assessing whether jurisdictions conform with this standard is a central focus of the second half of this book.

In broad terms secrecy jurisdictions represent a global governance problem because they promote their tax and financial opacity to attract savings from wealthy foreign investors eager to evade tax obligations in their country of residence. In the case of traditional tax havens, such as the Cayman Islands, Luxembourg or Jersey, with their low tax rates and finance oriented economies, tax secrecy has served as a catalyst for the creation of a relatively large financial services sector that stands as the cornerstone of the local economy. Tax havens that follow this development 
strategy soon become politically and economically dependent on financial services and are naturally resistant to any proposal to enhance tax transparency given the fundamental threat it poses to their established business models. Less well understood is the fact that large developed economies which host significant financial centres also face similar incentives but act in a slightly different way given their twin goals of maximising revenue to fund their large government sector and their desire to attract mobile capital. In order to pursue these competing policy goals developed countries may promote a regime for enhancing tax transparency in order to ensure their citizens pay tax on their offshore investments while subtly trying to protect foreigners who invest in their economy from the provisions of the same regime (Picciotto 2011; Sharman 2006). In short, the desire simultaneously to maximise tax revenues while remaining attractive to foreign investment has led major states in the international tax regime to act hypocritically.

This dynamic can broadly explain the politics of international tax cooperation in recent decades. States that have lost significant revenue to international evasion have periodically proposed the creation of a more robust regime for tax information exchange, while those which stand to lose have resisted reform. Switzerland's response to the OECD's Harmful Tax Competition (HTC) project launched in 1998 (described in Chapter 3) perhaps provides the clearest and most significant example of this strategy. Rather than oppose the initiative directly, the Swiss government simply refused to participate in the regime and remained exempt from its provisions under the OECD's 'mutual agreement' procedures. This diplomatic tactic ultimately undermined the political legitimacy of the HTC project, but in the short term it ensured that Switzerland avoided scrutiny while non-OECD secrecy jurisdictions, many of whom competed with Swiss banks to attract funds, were subjected to the emerging tax transparency regime. This broad depiction of the politics of international tax cooperation (or lack thereof), with its emphasis on instrumentalism and competing state interests is broadly consistent with realist explanations of international relations and the belief that international cooperation will only exist to the extent that it is consistent with the interests of the key states in the international regime. There may be an element of truth in this stylised account, but as the empirical analysis presented in the following chapters will demonstrate, the reality is more nuanced and complex.

This book argues that effective international tax cooperation is critically dependent on the support of key states in the international tax regime. However, at an empirical level it also notes that support for cooperation between leading states in the regime has fluctuated in recent years. This evidence suggests that the policy preferences of key actors in the 
international tax regime, such as the United States, are defined by complex combinations of strategic, institutional and domestic political considerations. In order to analyse these processes the study adopts a grounded, inductive approach to assess the influence of key variables - including economic factors, domestic politics and international organisations - on shaping the international tax policy preferences of key states in the regime.

A second set of considerations that contributes to the complexity of international tax cooperation relates to the growing role of non-governmental actors in the international tax arena. Central in this regard are the political and commercial interests and strategies of the international banks and financial services providers that the regime is attempting to regulate. Here too the political landscape is characterised by complexity, with corporate actors promoting a range of policy positions from compliance to defiance depending on the scope of their operations and their outlook in relation to the likely effectiveness of the regime. All credible commentary on the politics of international taxation concedes that financial interests dominate the policy debate with all states acutely aware of the potential impact of regulatory changes on patterns of international investment. Financial interests may dominate, but since the onset of the financial crisis they are no longer the sole voice in the policy debate, with 'tax justice' NGOs, many of which are organised internationally, increasingly asserting themselves and successfully promoting the cause of tax transparency on the mainstream political agenda. In light of these important developments this book will assess the impact of non-state actors on international tax cooperation at both the international and domestic levels.

Finally, the analysis presented below is sensitive to the fact that the international tax arena is highly institutionalised. Indeed international organisations have played a prominent role in negotiating and promoting international tax standards since the League of Nations established a Fiscal Committee in the late 1920s (Picciotto 1992, ch.1), while tax matters have been a major focus on the OECD's agenda since its creation in 1961 (Carroll and Kellow 2011). The fact that the international tax arena is so deeply institutionalised provides an opportunity to assess the independent role of international organisations such as the OECD in promoting international tax cooperation. To this extent the book argues that while there is limited evidence of international organisations shaping national policy preferences through a process of institutional socialisation (Finnemore 1996; Checkel 2005), at the height of the crisis the OECD did play an important agenda-setting role in promoting international tax cooperation at successive G20 leaders' meetings.

Above all else this book seeks to describe and analyse the complex ways in which the financial crisis has transformed the politics of international 
tax cooperation. To this extent the financial crisis should be regarded as the changing context in which international cooperation has occurred rather than being an independent variable which can of itself explain the progress that has been made towards creating an effective regime for tax information exchange. The financial crisis may have been a profound catalyst for change in the international tax arena but the reform process described below has been heavily mediated by pre-existing agendas, institutions and actors. As Streeck and Thelen (2005) have argued, the governance response to the financial crisis can be characterised by continuity as well as change.

\section{THE FINANCIAL CRISIS AND THE DYNAMICS OF INTERNATIONAL TAX COOPERATION: A SUMMARY}

This book has two related objectives. The first is to explain the significant developments in the international tax regime that have occurred since 2009 and the role of the financial crisis in this process. Second the book offers tentative conclusions concerning the likely effectiveness of the regime and whether recent progress that has been made concerning international tax cooperation is cause for more general optimism in relation to establishing effective global economic governance in the aftermath of the financial crisis. Given these tasks Chapter 1 begins with an empirical overview of the nature of international taxation and the governance problems associated with it. This chapter notes that while there is a good deal of ambiguity and contestation about how to define and measure international tax evasion, there is a growing consensus that it is a significant and growing problem with profound implications for the financial sustainability of developed and developing economies alike. Having provided this broad context the chapter concludes by documenting some of the main tax avoidance and evasion strategies and the ways in which they are facilitated by lax regulation and a lack of transparency in secrecy jurisdictions.

Chapter 2 provides the theoretical foundations for the analysis that follows. Having provided a synoptic survey of the extant literature on international cooperation the chapter highlights the need to adopt a historically grounded research method that can give due consideration to the complex range of factors which influenced recent developments in the international tax regime. This account goes beyond a traditional narrative in that the analysis is designed to provide insights into the competing explanations of international regime change in the extant literature. In this sense the study aims to provide an empirically grounded explanation 
of regime change which is both animated by and contributes to existing theoretical debates on international cooperation.

Having outlined the research method employed in the study Chapters 3 to 6 provide a detailed empirical account of recent developments in the international tax regime. Chapter 3 traces the historical development of the international tax regime from its early twentieth-century origins through to the recent period of rapid change in the immediate aftermath of the financial crisis. A central goal of this chapter is to explain the factors which led to the failure of the OECD's first attempt, in the form of the Harmful Tax Competition (HTC) initiative, to create an international tax information exchange regime. After documenting the declining political commitment to the HTC initiative in the early 2000s Chapter 4 explains how the financial crisis resulted in renewed and unprecedented enthusiasm for international tax cooperation. Yet rather than being a natural and inevitable response to the financial crisis, the chapter argues that the G20's endorsement of the OECD's tax transparency regime was a product of deliberate and effective advocacy on the part of the OECD which was able to exploit world leaders' acute need to identify coherent and credible policy responses to an unprecedented situation. Having highlighted the OECD's important agenda-setting role the remainder of the chapter describes the subsequent creation of the Global Forum on Transparency and Exchange of Information for Tax Purposes and the new-found political enthusiasm for all manner of jurisdictions to participate in the Global Forum process.

The dramatic developments at the international level described in Chapter 4 may have grabbed headlines, but a central theme of the book is that patterns of international tax cooperation are profoundly influenced by domestic political and economic considerations. Reflecting this theme, Chapter 5 focuses on the domestic politics of international tax cooperation in the United States and Switzerland, two of the most significant states in the international tax regime. The chapter highlights how the financial crisis not only shaped the international political agenda but also had a profound impact on the domestic politics of international taxation. In the United States the onset of the financial crisis increased domestic political support for offshore tax initiatives, such as the Stop Tax Haven Abuse Act 2006, which preceded the crisis, while the dramatic escalation in government debt resulting from the crisis has motivated all sides of American politics to support policies aimed at enhancing tax enforcement and compliance. In Switzerland, the combined effect of the financial crisis and international tax evasion scandals involving large Swiss investment banks such as UBS has been to undermine the legitimacy of the Swiss government's otherwise stoic defence of bank secrecy. While the 
all-powerful banking industry remains opposed to tax and financial transparency there is growing recognition that the pre-crisis regime is politically unsustainable.

The analysis in Chapter 6 focuses on the implementation of tax information exchange agreements entered into at the height of the crisis. The chapter argues that the effectiveness of the entire regime is critically dependent on robust compliance given that states frequently fail fully to honour their international tax obligations. Notwithstanding these concerns the evidence suggests that the revised Global Forum, with its broad membership and enhanced peer review regime has made a positive contribution to compliance behaviour. Despite this progress many fundamental challenges remain, and with only one quarter of the Global Forum's members having been subjected to a complete 'phase two' review, it is too soon to draw definitive conclusions about the success of the regime. More importantly, Chapter 6 highlights the critical distinction between regime compliance (whether a jurisdiction meets its international obligations) and the more problematic issue of regime effectiveness (whether the regime successfully addresses the policy problem it was designed to solve). Unfortunately, on the question of regime effectiveness there is much less cause for optimism. A central concern here is that the OECD standard for tax information exchange on request, which was endorsed by the G20 in 2009 and has been the focus of the Global Forum's subsequent work, may be ineffective in detecting and deterring international tax evasion. This has been the main criticism of tax justice NGOs who highlight the 'creeping futility' associated with promoting what they regard as a flawed standard for tax information exchange (Meinzer 2012). While few disagree that automatic information exchange of tax and financial information between tax authorities would be a highly desirable and potent weapon in the fight against international tax evasion, the chapter argues that if key states in the regime maintain their resolve to tackle international tax evasion then the standard currently being promoted by the Global Forum may be an intermediate step on the path to broad-based automatic information exchange. The OECD's July 2012 report on developing and implementing automatic information exchange represents progress towards this goal, but success is far from assured. The history of international tax cooperation is one of variable political commitment with periods of firm resolve interspersed with years of complacency and neglect. Ultimately the future of international tax cooperation is critically linked to broader developments in the international political economy and whether the progress that was made in terms of promoting international economic cooperation at the height of the financial crisis can be institutionalised and consolidated. 


\section{BEYOND THE FINANCIAL CRISIS: REGIME SUSTAINABILITY AND THE FUTURE OF GLOBAL ECONOMIC GOVERNANCE}

The future of international tax cooperation is inextricably linked to broader developments in global economic governance and the critical question of whether the international community is capable of developing and sustaining collective responses to the challenges facing the global economy in the aftermath of the financial crisis. Given the governance challenges associated with international tax cooperation, and the ever present economic incentives for secrecy jurisdictions to defect from commitments to exchange tax information, the sustainability of the international tax regime is highly dependent on effective global institutions and leadership. Unfortunately the institutional architecture of the global economic system remains in a state of flux and, as a consequence, the outlook for effective global economic governance remains uncertain. On a positive note, as is described in Chapter 4, the acute threat of global financial calamity which prevailed in 2008 and 2009 did prompt unprecedented international economic cooperation. However, as the financial crisis has evolved, and the political priorities of world leaders have gradually shifted from promoting international cooperation and solidarity to managing crisis-induced domestic political imperatives and pressures, the spirit of international economic cooperation has gradually waned. Even the G20 Leaders' Forum, which is widely regarded as the most significant institutional response to the crisis is being subjected to growing criticism for being unrepresentative and increasingly divided (Vestergaard 2011; Wade 2011). Similar political dynamics can also be observed within the eurozone, as a spirit of solidarity has given way to conflict over the terms of financial bailouts and who should fund them.

Arguably the root cause of the nascent mercantilism emerging in the global economy is a lack of leadership in the international system. Liberal international relations scholars have rightly argued that hegemonic groups can use international institutions to provide effective international leadership, but the reality of the post-financial crisis world order is that existing international economic institutions are struggling to adapt to the new political and economic reality, with commentators such as Jeffrey Sachs arguing that the financial crisis and its aftermath highlight the lack of transatlantic leadership (Sachs 2011). The financial crisis may have increased the relative economic power of China and the other so-called BRIC economies (those of Brazil, Russia and India as well as China) but it is equally apparent that the global economy is entering a significant period of transition. As Robert Wade $(2011,347)$ has argued 
The United States remains the dominant state, and the G7 states together continue to exercise primacy, but now more fearfully and defensively. China is split between asserting itself as 'the wave of the future' and defending itself as too poor to take on global responsibilities (it is roughly 100 th in the per capita income hierarchy). The combination of G7 defensiveness and emerging states' jealous guarding of sovereignty produces a spirit of Westphalian assertion in international fora, or 'every state for itself.'

As will be revealed in subsequent chapters these broader political dynamics are evident in the international tax regime. The push to enhance tax transparency has been very much a transatlantic project, with periodic interventions from China, India and other emerging economic powers. The Global Forum may have made real progress in allowing non-OECD states to participate in the international tax regime but it is important to acknowledge the fundamental difference between participation and tacit consent and providing diplomatic and financial leadership. In this sense the politics of international tax cooperation is symptomatic of the broader challenges associated with governing the global economy in the aftermath of the financial crisis, with the extent and nature of international cooperation increasingly dependent on the foreign economic policy priorities of China and other emerging powers.

\section{REFERENCES}

Blue, J. (2000) 'The Celtic Tiger Roars Defiantly: Corporation Tax in Ireland and Competition within the European Union', Duke Journal of Comparative and International Law, 10, 443-67

Carroll, Peter and Aynsley Kellow (2011) OECD: A Study of Organisational Adaptation, Cheltenham, UK and Northampton, MA, USA: Edward Elgar.

Checkel, Jeffrey T. (2005) 'International Institutions and Socialization in Europe: Introduction and Framework', International Organization, 59 (4), 801-26.

Finnemore, Martha (1996) National Interests in International Society, Ithaca, NY: Cornell University Press.

Gurría, Angel (2009) 'Remarks by Angel Gurría at the Global Forum on Transparency and Exchange of Information', available at: http://www.oecd. org/document/7/0,3746,en_2649_33767_43596999_1_1_1_1,00.html (accessed November 2011).

Hollingshead, Ann (2010) Privately Held, Non-Resident Deposits in Secrecy Jurisdictions, Global Financial Integrity, available at: http://www.gfinteg rity.org/storage/gfip/documents/reports/gfi_privatelyheld_web.pdf (accessed November 2011).

Keohane, Robert (2009) 'The Old International Political Economy and the New', Review of International Political Economy, 16 (1), 34- 46.

Martin, Isaac (ed.) (2009) The New Fiscal Sociology: Taxation in Comparative and Historical Perspective, Cambridge: Cambridge University Press. 
Meinzer, Markus (2012) 'The Creeping Futility of the Global Forum's Peer Reviews', Tax Justice Network Tax Justice Briefing - March 2012, available at: http://www.taxjustice.net/cms/upload/GlobalForum2012-TJN-Briefing.pdf (accessed March 2012).

OECD (2000) Improving Access to Bank Information for Tax Purposes, available at: http://www.oecd.org/dataoecd/3/7/2497487.pdf (accessed June 2011).

Palan, Ronen, Richard Murphy and Christian Chavagneux (2010) Tax Havens: How Globalization Really Works, Ithaca, NY: Cornell University Press.

Picciotto, Sol (1992) International Business Taxation: A Study in the Internationalization of Business Regulation, London: Weidenfeld and Nicolson.

Picciotto, Sol (2011) Regulating Global Corporate Capitalism, Cambridge: Cambridge University Press.

Sachs, Jeffrey (2011) 'Tripped up by Globalisation', Financial Times, 18 August.

Sharman, Jason (2006) Havens in the Storm, Ithaca: Cornell University Press.

Streeck, Wolfgang and Kathleen Thelen (2005) Beyond Continuity: Institutional Change in Advanced Political Economies, Oxford: Oxford University Press.

Tax Justice Network (2007) 'Identifying Tax Havens and Offshore Finance Centres', Tax Justice Network Briefing Paper, available at: http://www.taxjustic e.net/cms/upload/pdf/Identifying_Tax_Havens_Jul_07.pdf (accessed July 2012).

Vestergaard, Jakob (2011) 'The G20 and Beyond: Towards Effective Global Economic Governance', Danish Institute for International Studies, available at: http://www.diis.dk/graphics/publications/reports2011/rp2011-04-g20-and-beyo nd_web.pdf (accessed January 2012).

Wade, Robert (2011) 'Emerging World Order? From Multipolarity to Multilateralism in the G20, the World Bank, and the IMF', Politics and Society, 39 (3), 347-78.

Webb, Michael (2004) 'Defining the Boundaries of Legitimate State Practice: Norms, Transnational Actors and the OECD's project on Harmful Tax Competition', Review of International Political Economy, 11, 37-58.

Young, Oran R. (1999) Governance in World Affairs, Ithaca: Cornell University Press. 